Tropical Journal of Pharmaceutical Research January 2016; 15 (1): 201-211

ISSN: $1596-5996$ (print); 1596-9827 (electronic)

(C) Pharmacotherapy Group, Faculty of Pharmacy, University of Benin, Benin City, 300001 Nigeria.

All rights reserved.

Available online at http://www.tjpr.org

Review Article

http://dx.doi.org/10.4314/tjpr.v15i1.28

\title{
Nanoformulations and Clinical Trial Candidates as Probably Effective and Safe Therapy for Tuberculosis
}

\author{
Madeeha Laghari, Yusrida Darwis*, Abdul Hakeem Memon, Arshad Ali Khan, \\ Ibrahim Mohammed Tayeb Abdulbaqi and Reem Abou Assi \\ School of Pharmaceutical Sciences, Universiti Sains Malaysia, 11800, Pulau, Penang, Malaysia
}

*For correspondence: Email: yusrida@usm.my; Tel: 00604-6532211, 0060164670209; Fax: 00604-6570017

Received: 23 June 2015

Revised accepted: 30 November 2015

\begin{abstract}
Tuberculosis (TB) is the main infectious disease causing 1.8 million deaths worldwide every year and represents a principal cause of mortality resulting from a bacterial infection. The emergence of multidrug-resistant strains and lack of effective anti-TB drugs are threatening the future control of TB. The present multidrug regimen against TB needs daily administration for at least 6 months, and patients often fail to follow this complex regimen for such a long interval, thus leading to patient non-compliance and treatment related side effects. To avoid daily dosing, application of nanotechnology is a promising solution by virtue of sustained drug release. Nanotechnology-based rational targeting may improve therapeutic success by limiting adverse drug effects and requiring less frequent administration regimens, ultimately resulting in higher patient compliance, and thus attain higher adherence levels. Today, the pipeline of potential new treatments consists of several compounds in clinical trials or preclinical development with promising activities against sensitive and resistant Mycobacterium tuberculosis strains. Encapsulation of existing anti-TB drugs into nano-delivery systems and introduction of new drugs in combination treatment for all forms of tuberculosis have resulted in novel treatments with more effectiveness and reduced side effects.
\end{abstract}

Keywords: Tuberculosis, Nanotechnology, Anti-tuberculosis drugs, Nano carriers, Rifampicin

Tropical Journal of Pharmaceutical Research is indexed by Science Citation Index (SciSearch), Scopus, International Pharmaceutical Abstract, Chemical Abstracts, Embase, Index Copernicus, EBSCO, African Index Medicus, JournalSeek, Journal Citation Reports/Science Edition, Directory of Open Access Journals (DOAJ), African Journal Online, Bioline International, Open-J-Gate and Pharmacy Abstracts

\section{INTRODUCTION}

Tuberculosis (TB) is one of the significant contagious diseases worldwide and its frequency is increasing principally in association with AIDS pandemic. TB is not an addition in the recently discovered array of diseases but an ancient human disease that dates back to decades, however still it can be enumerated as one of the most prevalent and life threatening disease [1]. Despite the accessibility to cost saving and effective medication, TB is still held responsible for countless cases of active diseases and innocent avoidable deaths worldwide [2].
Unfortunately, the heartbreaking failure is the inability to cope up with the prevailing drug resistant strains of TB, examples of which are multi drug resistant (MDR) TB and extensively drug resistant (XDR) TB which are acutely adverse and life threatening [3]. Due to wide spread MDR-TB strains, world has encountered painful failure in wiping away this disease completely. It has been generally determined that patients without a fragment of hope and totally down-hearted may not continue the therapy because of side effects, prolong treatment, or relief of the symptoms. 
Strictly speaking, TB is one of such unfortunate diseases for which very limited antibiotics are discovered and very few are in pipeline. Figure 1 shows some of the major milestones in the discovery and development of drugs and regimens for TB. Rifampicin (RIF), isoniazid $(\mathrm{INH})$, pyrazinamide (PYZ), and ethambutol $(E M B)$ are the primary most choices for the clinical disease management. Internationally acknowledged $90 \%$ efficient, authentic treatment of active tuberculosis with HIV dormant consists of 6 months chemotherapy regimen using a combination of 4 drugs (RIF, INH, EMB, PYZ) daily for two months followed by RIF and INH for 4 months either daily or three times per week [4].

Discovery of Anti-TB Drugs

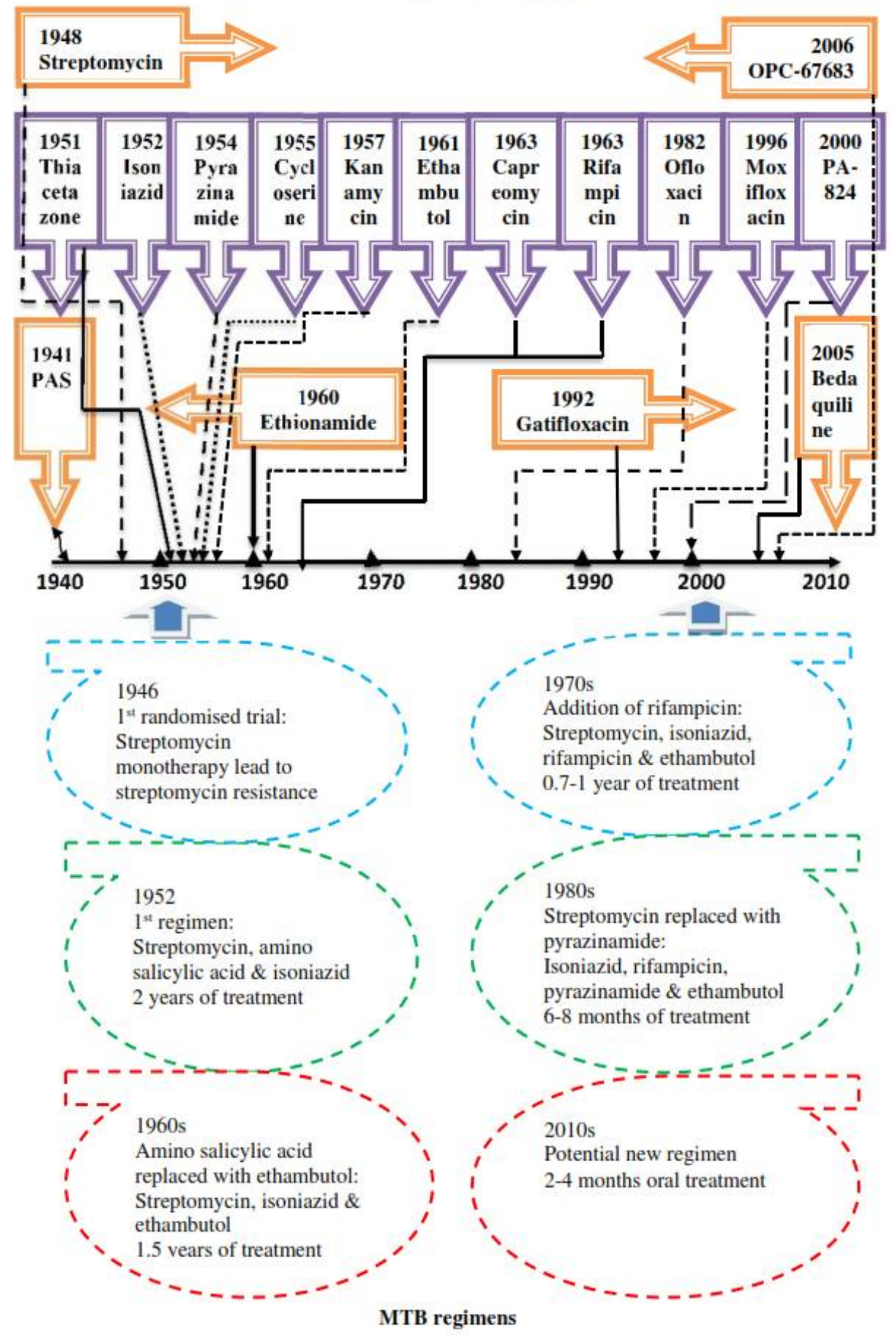

Figure 1: History, discovery and development of Anti-TB drug regimens 
First line therapy is a refined combination of these 4 drugs with addition of streptomycin (STR). For more advanced complex drug resistant strains MDR-TB and XDR-TB, suggested treatment includes the recommendation of any fluoroquinolone, together with at least one of three second-line injectable anti-TB drugs i.e. amikacin and capreomycin [5]. Targeted sites, doses, pharmacological and adverse effects of anti-TB drugs are summarized in Table 1.

Treatment of TB is composite and is becoming more and more composite with the emergence of MDR and HIV infection. Daily administration of combined antibiotic therapy of TB for at least six months may cause the early ending of treatment due to side effects or alleviation of primary symptoms which may lead to MDR-TB and XDRTB. Drug delivery systems using encapsulation technology is likely to perform its role by formulating anti-TB drugs into sustained release systems. Hence, encapsulation of current anti-TB drugs into nano delivery systems should be viewed to increase drug concentration at infected sites, improve their therapeutic index, reducing toxic effects and extent of treatment [6].

The aim of the present review is to highlight the potential advantages of these nanoparticles significant to the treatment of TB. Moreover, the safety and efficacy of new drugs in addition to an optimized standard therapy for the treatment of multidrug-resistant TB, also discussed.

Table 1: Current anti-TB drugs therapy in clinical use and their targets

\begin{tabular}{|c|c|c|c|c|}
\hline Drug & Daily dose & Targeted site & Effects & Adverse Effects \\
\hline \multicolumn{5}{|l|}{$\underline{1}^{\text {st }}$ Line drugs } \\
\hline Isoniazid & $\begin{array}{l}5 \mathrm{mg} / \mathrm{kg} \\
(\leq 300 \mathrm{mg})\end{array}$ & $\begin{array}{l}\text { Enoyl-acyl carrier } \\
\text { protein reductase } \\
\text { (also called InhA) }\end{array}$ & $\begin{array}{l}\text { Inhibits the } \\
\text { biosynthesis of } \\
\text { mycolic acids }\end{array}$ & $\begin{array}{l}\text { Rash, fever, jaundice, } \\
\text { peripheral neuritis, } \\
\text { hypersensitivity and } \\
\text { haematological } \\
\text { reactions }\end{array}$ \\
\hline Rifampicin & $\begin{array}{l}10 \mathrm{mg} / \mathrm{kg} \\
(\leq 600 \mathrm{mg})\end{array}$ & $\begin{array}{l}\text { Subunit of DNA- } \\
\text { dependent RNA } \\
\text { polymerase }\end{array}$ & $\begin{array}{l}\text { Inhibition of RNA } \\
\text { synthesis }\end{array}$ & $\begin{array}{l}\text { Rash, fever, nausea, } \\
\text { vomiting and hepatitis }\end{array}$ \\
\hline Pyrazinamide & $\begin{array}{l}15-30 \mathrm{mg} / \mathrm{kg} \\
(\leq 2 \mathrm{~g})\end{array}$ & $\begin{array}{l}\text { S1 component of } 30 \text { s } \\
\text { ribosomal subunit }\end{array}$ & $\begin{array}{l}\text { Inhibits translation } \\
\text { and trans- } \\
\text { translation }\end{array}$ & $\begin{array}{l}\text { Jaundice, hepatitis } \\
\text { and hyperuricemia }\end{array}$ \\
\hline Ethambutol & $\begin{array}{l}15-25 \mathrm{mg} / \mathrm{kg} \\
(\leq 1.2 \mathrm{~g})\end{array}$ & $\begin{array}{l}\text { Arabinosyl } \\
\text { transferases }\end{array}$ & $\begin{array}{l}\text { Inhibits } \\
\text { arabinogalactan } \\
\text { biosynthesis }\end{array}$ & $\begin{array}{l}\text { Optic neuritis, rash } \\
\text { and GIT upset }\end{array}$ \\
\hline \multicolumn{5}{|l|}{$\underline{2}^{n a}$-Line drugs } \\
\hline Streptomycin & $\begin{array}{l}15 \mathrm{mg} / \mathrm{kg} \\
(\leq 1 \mathrm{~g})\end{array}$ & $\begin{array}{l}\text { S12 and } 16 S \text { rRNA } \\
\text { components of } 30 S \\
\text { ribosomal subunit }\end{array}$ & $\begin{array}{l}\text { Inhibits protein } \\
\text { synthesis }\end{array}$ & $\begin{array}{l}\text { Ototoxicity, } \\
\text { nephrotoxicity, } \\
\text { paresthesia and } \\
\text { dysfunction of the } \\
\text { optic nerve }\end{array}$ \\
\hline Kanamycin & $\begin{array}{l}15 \mathrm{mg} / \mathrm{kg} \\
(\leq 1.5 \mathrm{~g})\end{array}$ & $\begin{array}{l}\text { 30s ribosomal } \\
\text { subunit }\end{array}$ & $\begin{array}{l}\text { Inhibits protein } \\
\text { synthesis }\end{array}$ & $\begin{array}{l}\text { Ototoxicity and } \\
\text { nephrotoxicity }\end{array}$ \\
\hline Amikacin & $\begin{array}{l}15 \mathrm{mg} / \mathrm{kg} \\
(\leq 1.5 \mathrm{~g})\end{array}$ & $\begin{array}{l}\text { 30s ribosomal } \\
\text { subunit }\end{array}$ & $\begin{array}{l}\text { Inhibits protein } \\
\text { synthesis }\end{array}$ & $\begin{array}{l}\text { Ototoxicity and } \\
\text { nephrotoxicity }\end{array}$ \\
\hline Capreomycin & $\begin{array}{l}15-30 \mathrm{mg} / \mathrm{kg} \\
(\leq 1 \mathrm{~g})\end{array}$ & $\begin{array}{l}\text { Inter bridge B2a } \\
\text { between } 30 \text { s and } 50 \text { s } \\
\text { ribosomal subunit }\end{array}$ & $\begin{array}{l}\text { Inhibits protein } \\
\text { synthesis }\end{array}$ & $\begin{array}{l}\text { Hearing loss, tinnitus, } \\
\text { eosinophilia, transient } \\
\text { proteinuria, and } \\
\text { nitrogen retention }\end{array}$ \\
\hline $\begin{array}{l}\text { Para-aminosalicylic } \\
\text { acid }\end{array}$ & $10-12 \mathrm{~g}$ & $\begin{array}{l}\text { Dihydropteroate } \\
\text { synthase }\end{array}$ & $\begin{array}{l}\text { Inhibits folate } \\
\text { biosynthesis }\end{array}$ & $\begin{array}{l}\text { GIT disturbance, High } \\
\text { fever Hypersensitivity, } \\
\text { and hematological } \\
\text { abnormalities }\end{array}$ \\
\hline Cycloserine & $\begin{array}{l}15-20 \mathrm{mg} / \mathrm{kg} \\
(\leq 1 \mathrm{~g})\end{array}$ & $\begin{array}{l}\text { D-alanine racemase } \\
\text { and ligase }\end{array}$ & $\begin{array}{l}\text { Inhibits } \\
\text { peptidoglycan } \\
\text { synthesis }\end{array}$ & $\begin{array}{l}\text { Most commonly } \\
\text { involve the CNS }\end{array}$ \\
\hline $\begin{array}{l}\text { Fluoroquinolones } \\
\text { (Gatifloxacin \& } \\
\text { Moxifloxacin) }\end{array}$ & $\begin{array}{l}400 \mathrm{mg} / \mathrm{kg} \\
(\leq 2 \mathrm{~g})\end{array}$ & $\begin{array}{l}\text { DNA gyrase and } \\
\text { topoisomerase IV }\end{array}$ & $\begin{array}{l}\text { Inhibits DNA } \\
\text { supercoiling }\end{array}$ & $\begin{array}{l}\text { GIT discomfort, } \\
\text { headache, dizziness } \\
\text { and rashes }\end{array}$ \\
\hline
\end{tabular}




\section{NANO CARRIER SYSTEMS}

Nanotechnology and Nano science studies are a warm-heartedly welcomed revolution in a modern era of advancement. These studies have dramatically emerged during the last few decades in a vast field of product domains and have captured enormously generous attention due to their compact size properties [7].

Table 2: Nanoformulations of anti-TB drugs

\begin{tabular}{|c|c|c|c|c|c|}
\hline $\begin{array}{l}\text { Route of } \\
\text { administrati } \\
\text { on }\end{array}$ & $\begin{array}{l}\text { Drug delivery } \\
\text { system }\end{array}$ & $\begin{array}{l}\text { Animal } \\
\text { model }\end{array}$ & Observation & Significance of study & Ref \\
\hline Oral & SLN & Mice & $\begin{array}{l}\text { RIF, INH \& PYZ SLNs were } \\
\text { detected } 8 \text { days in plasma and } \\
10 \text { days in organs rich in MPS }\end{array}$ & $\begin{array}{l}5 \text { oral doses of SLNs at every } \\
10^{\text {th }} \text { day completely } \\
\text { suppressed bacterial load. } \\
\text { Improved bioavailability and } \\
\text { reduced dosing frequency }\end{array}$ & {$[8]$} \\
\hline Oral & SLN & Rats & $\begin{array}{l}t_{1 / 2}, C_{\max } \text { and } A U C \text { increased } \\
\text { with respect to that achieved } \\
\text { with the free drug }\end{array}$ & $\begin{array}{l}\text { There was } 6 \text { times increased } \\
\text { bioavailability in plasma and } 4 \\
\text { times in brain. INH-SLN } \\
\text { showed a } 3 \text { times higher } \\
\text { LD }_{50} \text { in comparison to free } \\
\text { INH }\end{array}$ & [9] \\
\hline Aerosol & SLN & Rats & $\begin{array}{l}\text { The viability of alveolar } \\
\text { macrophages and alveolar } \\
\text { epithelial type II cells was } \\
\text { above } 80 \% \text { with RIF-SLNs }\end{array}$ & $\begin{array}{l}\text { RIF-SLN exhibited low toxicity } \\
\text { comparatively to free drug }\end{array}$ & [10] \\
\hline Oral & $\begin{array}{l}\text { PLGA } \\
\text { Polymeric } \\
\text { nanoparticles }\end{array}$ & Mice & $\begin{array}{l}\text { Encapsulated RIF was } \\
\text { detected in plasma up to } 6 \\
\text { days whereas INH and PYZ for } \\
9 \text { days }\end{array}$ & $\begin{array}{l}\text { No TB was detected in tissues } \\
\text { after administration of } 5 \text { doses } \\
\text { of drug-loaded nanoparticles }\end{array}$ & [11] \\
\hline Oral & $\begin{array}{l}\text { PLG } \\
\text { Polymeric } \\
\text { nanoparticles }\end{array}$ & $\begin{array}{l}\text { Guinea } \\
\text { pigs }\end{array}$ & $\begin{array}{l}\text { Nanoparticles increased } \\
\text { plasma concentration of RIF } \\
\text { for } 6-7 \text { and } 13-14 \text { days for INH } \\
\text { and PYZ }\end{array}$ & $\begin{array}{l}\text { Increase in bioavailability of } \\
\text { drugs and therapeutic effects } \\
\text { were achieved even at low } \\
\text { frequent dosing }\end{array}$ & [12] \\
\hline Oral & $\begin{array}{l}\text { Alginate } \\
\text { based } \\
\text { Polymeric } \\
\text { nanoparticles }\end{array}$ & Mice & $\begin{array}{l}\text { Therapeutic concentration of } \\
\text { RIF, INH and EMB } \\
\text { nanoparticles was observed } \\
\text { for } 7-11 \text { days in plasma and } 15 \\
\text { days in lungs, liver and spleen }\end{array}$ & $\begin{array}{l}3 \text { oral doses of polymeric } \\
\text { formulations at } 15 \text { days } \\
\text { interval resulted in complete } \\
\text { bacterial clearance from } \\
\text { organs compared to } 45 \\
\text { conventional doses of free } \\
\text { drugs. Increased bioavailability } \\
\text { was observed }\end{array}$ & [13] \\
\hline $\mathrm{I} / \mathrm{V}$ & $\begin{array}{l}\text { Manno } \\
\text { sylated gelatin } \\
\text { nanoparticles }\end{array}$ & Mice & $\begin{array}{l}\text { INH loaded nanoparticles } \\
\text { resulted in significant reduction } \\
\text { in bacterial counts }\end{array}$ & $\begin{array}{l}\text { Nanoparticles showed almost } \\
9 \text {-fold higher drug content in } \\
\text { lungs and 6-fold higher in liver }\end{array}$ & [14] \\
\hline Aerosol & $\begin{array}{l}\text { PLG } \\
\text { Polymeric } \\
\text { nanoparticles }\end{array}$ & $\begin{array}{l}\text { Guinea } \\
\text { pigs }\end{array}$ & $\begin{array}{l}\text { Sustained therapeutic drug } \\
\text { levels were observed for } 6-8 \\
\text { days in plasma and } 11 \text { days in } \\
\text { lungs }\end{array}$ & $\begin{array}{l}\text { Increase in bioavailability. No } \\
\text { TB was detected after } 5 \text { doses } \\
\text { of treatment at every } 10^{\text {th }} \text { day } \\
\text { whereas } 46 \text { daily doses of free } \\
\text { drugs were required to attain } \\
\text { equivalent effects. }\end{array}$ & [15] \\
\hline $\mathrm{S} / \mathrm{C}$ & $\begin{array}{l}\text { PLG } \\
\text { Polymeric } \\
\text { nanoparticles }\end{array}$ & Mice & $\begin{array}{l}\text { Sustained therapeutic drug } \\
\text { levels were observed for } 32 \\
\text { days in plasma and } 36 \text { days in } \\
\text { lungs/spleen }\end{array}$ & $\begin{array}{l}\text { Nanoparticles increased the } \\
\text { drug bioavailability and } \\
\text { reduced dosing frequency }\end{array}$ & [16] \\
\hline $\begin{array}{l}\mathrm{I} / \mathrm{V} \text { and } \\
\text { intratracheal }\end{array}$ & Niosomes & Rats & $\begin{array}{l}\text { AUC study of RIF niosomes } \\
\text { indicated a higher organ to } \\
\text { serum AUC ratio as compared } \\
\text { to free drug }\end{array}$ & $\begin{array}{l}\text { RIF-niosomes exhibited } \\
\text { significant targeted delivery }\end{array}$ & [17] \\
\hline I/V & Liposomes & Mice & $\begin{array}{l}\text { Increased activity of amikacin } \\
\text { against } M T B \text { and improved } t_{1 / 2} \\
\text { of the drug encapsulated } \\
\text { liposomes compared with the } \\
\text { free drug ones }\end{array}$ & Reduced dosing frequency & [18] \\
\hline
\end{tabular}


Nanoparticle-based delivery systems propose a number of advantages and give way to a bright possibility of introducing different routes of drug administration for better management of the disease. Numerous attempts have been made by scientists to encapsulate anti-TB drugs into different types of nanoparticles. These formulations have shown better results in terms of bioavailability, dosing frequency, safety and duration of treatment when compared with standard therapy Table 2.

\section{Types of nanoparticles}

\section{(i) Liposomes}

Liposomes are accurately best defined as tiny spherical lipid globules with a bi-layered membrane structure consisting of natural or synthetic amphiphilic lipid molecules with an aqueous interior [19]. Liposomes are taken up by macrophages, release their contents intracellularly, and are effective against intracellular pathogens, e.g., M. tuberculosis. Deol et al developed liposomes (Stealth ${ }^{\circledR}$ ) which were more effective than free drugs for targeted delivery to the lungs. The free INH given at the therapeutic dose of $12 \mathrm{mg} / \mathrm{kg}$ and RIF at 10 $\mathrm{mg} / \mathrm{kg}$ reduced colony forming unit (CFU) to 4.5 and 4.3 log units in lungs, while the same doses of INH and RIF liposomes (Stealth $\AA$ ) reduced colony forming unit to 3.9 and 3.8 log units, respectively [20]. Labana et al developed liposomes containing an active targeting ligand O-steroyl amylopectin for encapsulation of RIF and $\mathrm{INH}$. The formulation also exhibited a sustained drug release for more than $120 \mathrm{~h}$, compared to $10 \mathrm{~h}$ for the free drugs and reduced the daily administration to only once a week [21]. Liposomes as nanocarrier drug delivery systems have also shown significant development in vaccines design for the treatment and prevention of TB. DNA vaccine combination expressing MTB heat shock protein 65 (HSP 65), IL-12, Ag85B-ESAT-6/CAF01 are the well-known examples of a vaccine liposomal-based technology with promising results [22].

\section{(ii) Nanoemulsions}

Nanoemulsions are defined as transparent or translucent water-in-oil (w/o) or oil-in-water (o/w) droplets with 10-100 nm mean droplet diameter [23].

Thermodynamically stable nanoemulsion of ramipril with mean particle size of $80.9 \mathrm{~nm}$ and polydispersity index of 0.271 was developed for oral administration. The relative bioavailability of ramipril nanoemulsion to that of conventional capsule and drug suspension were 229.62 and $539.49 \%$, respectively [24]. Ahmed et al developed various parenteral o/w nanoemulsions of RIF with excellent stability over 19 months [25].

\section{(iii) Solid lipid nanoparticles}

Back then in the middle 1990's, Solid lipid nanoparticles (SLNs), the sub-micron colloidal carrier, were formally introduced as a novel drugcarrier system for oral deliver [26]. SLNs have captured enormous attention by various researchers and companies owing to the controlled drug delivery, enhancement of bioavailability of entrapped drugs and/or improvement of tissue distribution and targeting of drugs. There is a very less concern about their safety and biocompatibility as they are generally made from physiological lipids and surfactants [27].

Durgaramani et al designed RIF loaded SLNs with highest encapsulation efficiency of $78.79 \%$ and in vitro release studies showed suitability of RIF-SLNs for the treatment of TB [28]. In 2013, Indu Pal Kaur incorporated RIF and INH into SLNs and studied the percent degradation of RIF in these combined SLNs (RIF-SLNs + INHSLNs). The results showed increased bioavailability and prolong release of RIF by decreasing its degradation in presence of $\mathrm{INH}$ [29].

\section{(iv) Polymeric nanoparticles}

Most of the polymeric nanoparticles are biodegradable and biocompatible and are preferred for the delivery of nano materials. Polymeric nanoparticles have been scrutinized to deliver a variety of antimicrobial agents to medicate various infectious diseases and have shown great therapeutic efficacy [30].

RIF, INH and STR loaded polymeric nanoparticles with elevated antimicrobial activity were prepared by Anisimova et al where encapsulated INH showed increased intracellular concentration of 4-8 folds, STR 7 folds and RIF 22-25 with respect to the extracellular concentration [31]. Correspondingly moxifloxacin loaded poly (n-butyl cyanoacrylate) nanoparticles delayed intracellular MTB growth at $0.1 \mu \mathrm{g} / \mathrm{mL}$, whereas free moxifloxacin has same effect at 1 $\mu \mathrm{g} / \mathrm{mL}$ [32]. Clemens et al employed mesoporous silica nanoparticle drug delivery systems either coated with a polyethyleneimine to release RIF or equipped with cyclodextrin based $\mathrm{pH}$ operated nanovalves that open only at acidic $\mathrm{pH}$ to release INH into MTB-infected macrophages. 
Polyethyleneimine coated meso-porous silica nanoparticle demonstrated much greater loading and potency of RIF against MTB infected macrophages than uncoated. INH delivered by meso-porous silica nanoparticle killed MTB within macrophages more adequately than an equivalent amount of free drug [33]. To enhance the intracellular bioavailability of INH a highly hydrophobic citral-derived INH analogue named JVA was encapsulated in PLGA nanoparticles. Results suggested that JVA-NPs diminish pathogen proliferation and also increased MTB killing inside macrophages due to increase bioavailability of INH [34].

\section{(v) Niosomes}

Described as non-ionic surfactant vesicles having a bi-layer structure formed by selfassembly of hydrated surfactant monomers. Niosomes are delivering drugs directly to the body part where the therapeutic effect is required. This reduces the dose frequency to achieve the desired effects which subsequently decrease the side effects [35].

INH loaded niosomes were prepared by Roopa Karki. In vivo drug disposition study was evaluated in normal healthy albino rats. Niosomal drug delivery exhibited lower toxicity and less accumulation of drug than the free drug. The in vitro release pattern indicating sustained release for $48 \mathrm{~h}$ [36]. In 2011, Shubhini prepared INH niosomes which remained in the targeted site for longer time and also maintained INH concentration up to $30 \mathrm{~h}$. The INH niosomes developed were capable of reducing drug dose and toxicity as well as dosing frequency which improved patient compliance [37]. In another study, Jain and Vyas developed micro-sized (8$15 \mu \mathrm{m})$ RIF loaded niosomes. It was revealed from in vivo studies that, depending upon the size of niosomes, up to $65 \%$ of the drug loaded niosomes found in the lungs. The RIF niosomes had lower toxicity and were efficiently up taken into the lungs [38].

Furthermore, in 2010, Pavalarani studied niosomes of RIF and gatifloxacin. The bactericidal activities of the niosomal formulation were particularly examined using the resistant strains (RF 8554) and sensitive strains (H37Rv) of MTB. The results showed that these niosomes had greater inhibition and reduced growth index [39]. El-Ridy et al studied PYZ niosomes with maximum concentration in lungs, less side effects and decreased toxicity [40].

\section{NEW ANTI-TUBERCULOSIS DRUG CANDIDATES IN CLINICAL TRIALS}

For the definite abolishment of TB; outdated drugs and regimens would offer no help. Instead there is a pressing need to make progress or development for new drugs but there are also some definite and comprehensible criteria for developing new TB drug candidates [41]. In addition to a fully confirmed safety profile, numerous other necessary factors should be fulfilled by a new anti-TB drug, that are: it should be more potent than existing drugs in order to reduce the duration of therapy; should inhibit new targets so that MDR-TB and XDR TB can be treated; be compatible with antiretroviral drugs; and show no antagonism to other TB drugs. Combining these new drugs with existing TB drugs revive hope for regimens that are better tolerated, shorter treatment duration and with less drug-drug interactions when compared with existing regimens For this purpose, various antiTB drugs have been synthesized and tested in vitro [42] showed novel mechanism of action (Figure 2).

These agents are expected to improve the treatment of drug-resistant, and possibly drugsusceptible TB used either separately or in combinations with standard therapy.

\section{(i) $\quad$ TMC207}

TMC207 formerly known as R207910 is the first anti-tubercular drug in the diarylquinoline class, with the MIC ranging from 0.002 to $0.06 \mu \mathrm{g} / \mathrm{mL}$. In Phase II trials for the treatment of smearpositive pulmonary MDR-TB, TMC-207 was examined at $400 \mathrm{mg} /$ day for 2 weeks, followed by $200 \mathrm{mg}$ thrice weekly. It was found effective and safe [43]. In guinea pigs, TMC-207 was given for 6 weeks resulted in nearly complete elimination of MTB from body [44]. In 2008, Anil Koul has demonstrated an increased susceptibility of dormant mycobacterium toward TMC-207 as compared with actively growing bacteria. TMC-207 at $10 \mu \mathrm{g} / \mathrm{mL}$ was highly potent and killed dormant bacilli, as no bacteria could be detected by 14th day [45]. The remarkable activity of the combination of TMC207 with PYZ in reducing the bacillary count by $5.6 \log _{10}$ CFU after 1 month of treatment that is higher by more than $2 \log _{10}$ CFU which obtained with the most effective drug combination without TMC-207, i.e., RIF-INH-PYZ [46]. 


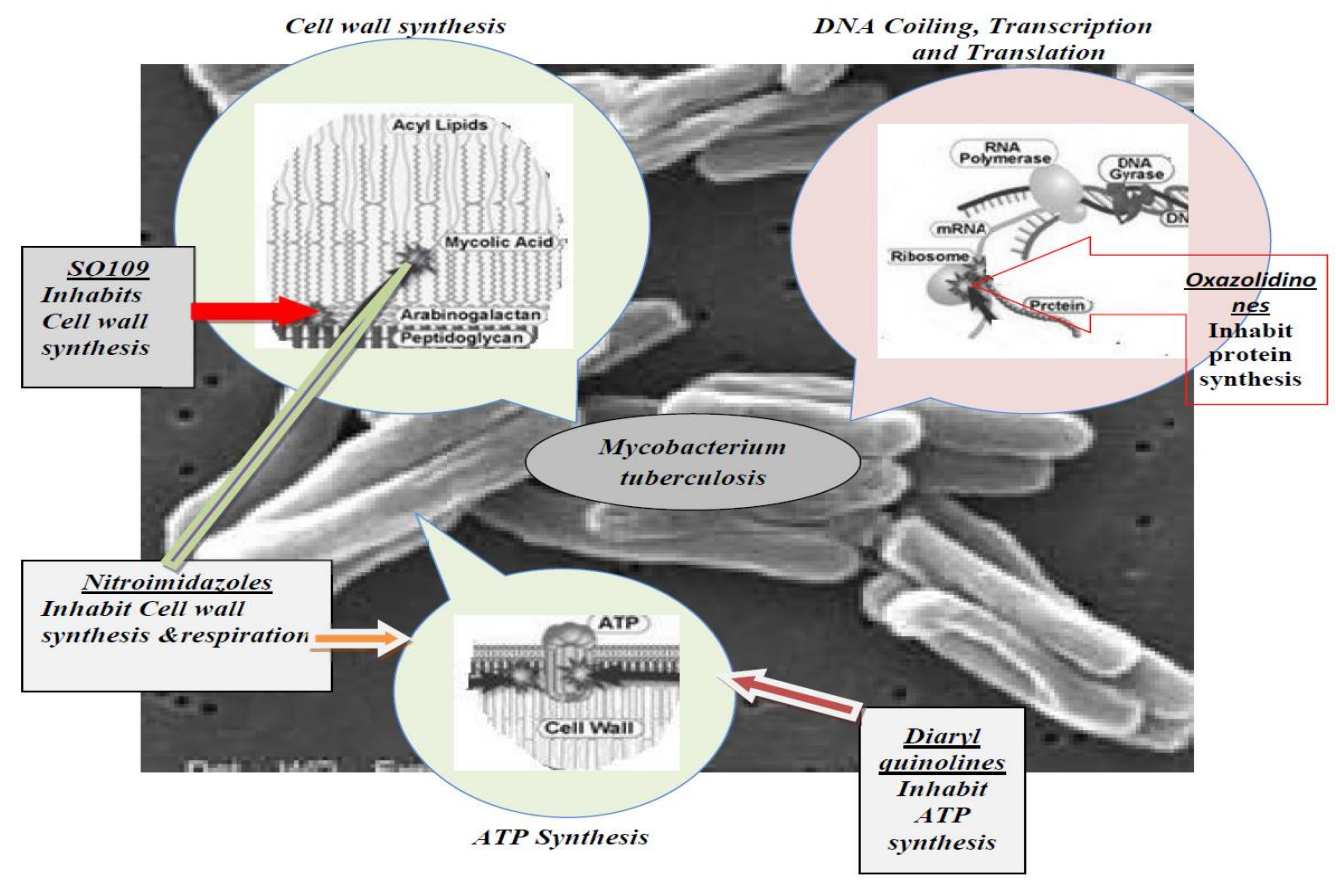

Figure 2: New anti-TB drugs with site of action

(ii)

\section{Nitroimidazoles}

Two new nitroimidazoles including PA-824 the lead compound from a series of nitroimidazoxazine derivatives and OPC-67683 (delamanid) the lead compound from a series of nitroimidazoxazole derivatives, are favourable drugs for TB. An early bactericidal activity study was performed to evaluate PA-824 orally at 200 , 600 and 1000 or $1200 \mathrm{mg} /$ day for 14 days. All doses were well tolerated, but unpredictably, showed comparable activity [47]. PA-824 exhibited significant anti-TB activity, with a $\mathrm{MIC}_{90}$ of $0.015-0.25 \mu \mathrm{gg} / \mathrm{mL}$ against both drugsusceptible and resistant strains of MTB [48].

TB Alliance completed the clinical trial NC001, to evaluate combination of three-drug regimen PA824, moxifloxacin and PYZ. The PYZ regimen presented substantially better effects than the standard treatment (HRZE) [49]. It is also markedly reassuring for MDR-TB patients who are susceptible to the drugs in the regimen, as it reduces the treatment from 2 years to 4 months together with being an efficiently economical and reasonable package costing just a fraction of the current MDR-TB treatment. It can be coadministered with common antiretroviral drugs, thereby improving treatment opportunity for patients co-infected with TB and HIV. PA-824 Studies in healthy volunteers showed $a t_{1 / 2}$ of about $18 \mathrm{~h}$ and a time to reach $\mathrm{C}_{\max }$ of 4 to $5 \mathrm{~h}$. About $65 \%$ of drug is excreted in urine and $26 \%$ in feces.
OPC-67683 is a nitro-dihydro-imidazooxazole and is closely related to PA-824. It inhibits the synthesis of methoxy and keto-mycolic acid, with MIC of $0.006-0.024 \mu \mathrm{g} / \mathrm{mL}$ and plasma half-life of $7.6 \mathrm{~h}$. OPC-67683 shows potent anti-TB activity against both replicating and nonreplicating bacteria and also against drugresistant MTB. Therapeutic efficacy of OPC67683 is evaluated in vivo in an experimental chronic TB mouse model, where OPC-67683 exhibited the most potent anti-TB activity in comparison with the reference compounds. A new regimen containing OPC-67683 could incomparably curtail the treatment extent by at least 2 months [50]. Killing activity of OPC-67683 was superior to INH and equal to RIF in an in vitro model of drug-tolerant MTB [51]. OPC67683 was tolerated well by healthy volunteers at multiple doses from 5 up to $400 \mathrm{mg}$ and no serious adverse effects were reported [52].

\section{(iii) Oxazolidinones}

(Linezolid, AZD5847 and PNU-100480) In addition to mycobacteria, Oxazolidinones possess a broad spectrum of antibiotic activity, against Gram positive aerobic and anaerobic bacteria [53]. Linezolid has demonstrated high in vitro antibacterial activity against MTB as well as MDR and XDR strains, with a minimum inhibitory concentration of less than $1 \mu \mathrm{g} / \mathrm{mL}$ [54]. Linezolid has been endorsed to be used at doses of 800 $1200 \mathrm{mg} /$ day in individual doses for the shortterm treatment of bacterial infections [55]. 
Table 3: Summary of some of the effective anti-TB drugs in clinical pipeline

\begin{tabular}{|c|c|c|c|c|}
\hline Drug & Sponsor & $\begin{array}{l}\text { Active } \\
\text { against }\end{array}$ & Efficacy Comparison to standard therapy & Ref \\
\hline TMC-207 & $\begin{array}{l}\text { Tibotec, } \\
\text { and the } \\
\text { Global } \\
\text { Alliance }\end{array}$ & $\begin{array}{l}\text { Susceptible } \\
\text { and MDR } \\
\text { strains }\end{array}$ & $\begin{array}{l}\text { In MTB-infected mice TMC207 at } 25 \mathrm{mg} / \mathrm{kg} \text { was as } \\
\text { effective as combination therapy of RIF/INH/PYZ } \\
\text { whereas the addition of TMC207 to this triple drug } \\
\text { regimen results in accelerated clearance of bacilli }\end{array}$ & [63] \\
\hline PA-824 & $\begin{array}{l}\text { Global } \\
\text { Alliance }\end{array}$ & $\begin{array}{l}\text { Susceptible } \\
\text { and MDR } \\
\text { strains }\end{array}$ & $\begin{array}{l}25 \text { to } 50 \mathrm{mg} / \mathrm{kg} \text { of PA-824 was compared to } 25 \mathrm{mg} / \mathrm{kg} \\
\text { of INH in mice and guinea pigs, } 20 \mathrm{mg} / \mathrm{kg} \text { RIF and } \\
100 \mathrm{mg} / \mathrm{kg} \text { of } \mathrm{MX} \text { in mice. PA- } 824 \text { showed greater } \\
\text { activity than INH and MX in vitro and in mice and } \\
\text { comparable activity to combination therapy with RIF } \\
\text { and INH }\end{array}$ & [52] \\
\hline OPC-67683 & $\begin{array}{l}\text { Otsuka } \\
\text { Pharmace } \\
\text { utical }\end{array}$ & MDR & $\begin{array}{l}\text { In mice, a regimen of OPC- } 67683(2.5 \mathrm{mg} / \mathrm{kg}) \text {, RIF ( } 5 \\
\mathrm{mg} / \mathrm{kg}) \text {, and PYZ (100 mg/kg) achieved faster } \\
\text { abolition of bacilli than the standard RHZE regimen } \\
(5,10,00 \text {, and } 100 \mathrm{mg} / \mathrm{kg}) \text {. No mycobacterial colonies } \\
\text { were detected after } 4 \text { months of treatment with } \\
\text { OPC } 67683-\text { containing regimen, Whereas colonies } \\
\text { were still detected after } 6 \text { months of treatment with the } \\
\text { standard regimen. }\end{array}$ & [52] \\
\hline $\begin{array}{l}\text { PNU- } \\
100480\end{array}$ & Pfizer & $\begin{array}{l}\text { Susceptible } \\
\text { and drug } \\
\text { resistant } \\
\text { TB }\end{array}$ & $\begin{array}{l}\text { In a murine model, inclusion of } \mathrm{PNU}-100480 \text { to } \\
\text { current first-line TB drugs or with } \mathrm{MX} \text { remarkably } \\
\text { exaggerates the bactericidal activity. The combination } \\
\text { of PNU-100480, MX, and PYZ, without RIF or INH, } \\
\text { was also more progressive than standard therapy }\end{array}$ & [64] \\
\hline SQ-109 & Sequella & $\begin{array}{l}\text { Susceptible } \\
\text { and drug } \\
\text { resistant } \\
\text { MTB isolates }\end{array}$ & $\begin{array}{l}\text { The combination of SQ109 with INH, RIF, and PZA in } \\
\text { study provided a new and very effective anti-TB } \\
\text { intensive phase treatment regimen that killed MTB at } \\
\text { a better and faster rate than the therapeutic regimen } \\
\text { of INH/RIF/EMB/PZA }\end{array}$ & [65] \\
\hline
\end{tabular}

Identical counterpart of linezolid, PNU-100480 is demonstrated slightly better in vitro activity. PNU100480 proved to be well tolerated when given at a dose of $1,000 \mathrm{mg} /$ day in healthy volunteers [56].

AZD5847 is another oxazolidinone to counterbalance the terrible cycle of TB, it is bactericidal and acts like linezolid. AZD5847 has similar MIC to linezolid and PNU-100480. It is well tolerated at daily oral doses of 800,1600 and $2400 \mathrm{mg}$ for 14 days in healthy volunteers with an increased $C_{\max }$ of $10 \mu \mathrm{g} / \mathrm{mL}$ [57]. In another study, AZD5847 exhibited an MIC90 of 1 $\mu \mathrm{g} / \mathrm{mL}$ and bactericidal activity of $2 \mu \mathrm{g} / \mathrm{mL}$ against both rapid-and sluggishly growing organisms when tested on MTB against laboratory strains and clinical isolates that are resistant to standard regimens [58].

\section{(iv) Ethylenediamines (SQ109)}

SQ109 is a 1,2-ethylenediamine ethambutol analogue [59] . In the mouse model, after an oral dose of $25 \mathrm{mg} / \mathrm{kg}, C_{\max }$ of SQ109 was approximately $0.14 \mu \mathrm{g} / \mathrm{mL}$ and the $t_{1 / 2}$ of $5.2 \mathrm{~h}$. After 28 days of treatment with $25 \mathrm{mg} / \mathrm{kg}$ of SQ109 or $100 \mathrm{mg} / \mathrm{kg}$ of EMB in MTB-infected mice, the lung CFU counts reduced by $2-\log _{10}$, as compared to $3-\log _{10}$ in control mice treated with
$25 \mathrm{mg} / \mathrm{kg}$ of INH [60]. In 2012, Venkata studied bactericidal activity of PNU and SQ109 against MTB in vitro and in macrophages. Both compounds have an exemplary activity alone and in combination with other anti-TB drugs in chronic TB mouse models [61]. SQ109 has synergistic effect with INH, and RIF and it has also activity against $\mathrm{EMB}$ resistant strains in vitro [62]. In 2005, Protopopova unveiled the activity of SQ109 against drug-resistant strains of MTB. SQ109 was able to lower the intracellular MTB count by $99 \%$ at its MIC of $1.56 \mathrm{mM}$. SQ109 demonstrated highest activity in vivo, mainly in lungs, and effective in curing TB infection in mice at $1 \mathrm{mg} / \mathrm{kg}$ while ethambutol at $100 \mathrm{mg} / \mathrm{kg}$ [59]. The list of TMC207, PA-824, OPC-67683, PNU100480 and SQ109 drugs used as potent drugs to shorten the treatment of MTB is shown in Table 3.

\section{CONCLUSION}

Regardless of all the laborious measures and overtures taken for making the treatment a conducive procedure, TB never ceases to be one of the phenomenal challenging threats encountered at global level.

The management of tuberculosis with anti-TB drugs chemotherapy dwells to be a difficult task. 
The cardinal reasoning for this is the development of resistance by microbes and severe uncertain blocks of conventional chemotherapy. Current therapeutic agents are life-saving for many patients, but fail to defeat MDR-TB/XDR-TB. The new anti-TB drugs are unquestionable needed to reduce the course of treatment, to compare against MDR- and XDRTB and also to be easily administered in combination with antiretroviral drugs. Though identifying novel anti-TB agents remain a priority, the development of new formulations such as nano carrier systems to deliver existing anti-TB agents to the affected site is one of the alternatives to improve TB chemotherapy. Nano technology has a significant potential within the realm of possibility for treatment of TB, as it can improve drug bioavailability and reduce dosing frequency that may create a sound basis for better management of the disease. To top it all auxiliary anti-TB drugs offer the promise of shortened treatment regimens for drug-sensitive disease and more effective treatment for drugresistant disease and latent infection, and also offer hope for future tuberculosis control.

\section{ACKNOWLEDGEMENT}

The authors would like to thank Universiti Sains Malaysia for providing Research University grant (no. 1001/P Farmasi/811285) to support this work.

\section{REFERENCES}

1. Ehsan A, Massoumeh $N$, Narges $G$, Fatemeh $A$, Mohammad RF, Hossein J, Rassoul D. Improved antimycobacterial activity of rifampin using solid lipid nanoparticles. Int Nano Lett 2012; 2(1): 1-8.

2. Zumla A, Raviglione $M$, Hafner R, Fordham von Reyn $C$. Tuberculosis. N Engl J Med 2013; 368(8): 745-755.

3. Young $D B$, Perkins $M D$, Duncan $K$, Barry $C E$. Confronting the scientific obstacles to global control of tuberculosis. J Clin Invest 2008; 118(4): 1255-1265.

4. Jia L, Noker PE, Coward L, Gorman GS, Protopopova M, Tomaszewski JE. Interspecies pharmacokinetics and in vitro metabolism of SQ109. Br J Pharmacol 2006; 147(5): 476-485.

5. Hum NJ, Sungweon R. First- and Second-Line Drugs and Drug Resistance; 2013.

6. Gaspar MM, Cruz A, Penha AF, Reymao J, Sousa AC, Eleuterio CV, Domingues SA, Fraga AG, Filho AL, Cruz $M E$, et al. Rifabutin encapsulated in liposomes exhibits increased therapeutic activity in a model of disseminated tuberculosis. Int $\mathrm{J}$ Antimicrob Agents 2008; 31(1): 37-45.

7. Anthony $A A$, Mumuni AM, Philip FB. Lipid Nanoparticulate Drug Delivery Systems: A Revolution in
Dosage Form Design and Development. In: Sezer AD editor. Recent Advances in Novel Drug Carrier Systems: InTech; 2012. p 108-140.

8. Pandey R, Sharma S, Khuller GK. Oral solid lipid nanoparticle-based antitubercular chemotherapy. Tuberculosis (Edinb) 2005; 85(5-6): 415-420.

9. Bhandari $R$, Kaur IP. Pharmacokinetics, tissue distribution and relative bioavailability of isoniazid-solid lipid nanoparticles. Int J Pharm 2013; 441(1-2): 202-212.

10. Junlan C, Yanzhen L, Likai Y, Xun S, Qiang Z, Tao G, Zhirong Z. Enhanced rifampicin delivery to alveolar macrophages by solid lipid nanoparticles. J Nanopart Res 2013; 15(5): 1-9.

11. Pandey R, Zahoor A, Sharma S, Khuller GK. Nanoparticle encapsulated antitubercular drugs as a potential oral drug delivery system against murine tuberculosis. Tuberculosis (Edinb) 2003; 83(6): 373-378.

12. Anjali S, Sadhna S, Khuller GK. Lectin-functionalized poly (lactide-co-glycolide) nanoparticles as oral/aerosolized antitubercular drug carriers for treatment of tuberculosis. J Antimicrob Chemother 2004; 54(4): 761-766.

13. Ahmad Z, Pandey R, Sharma S, Khuller GK. Alginate nanoparticles as antituberculosis drug carriers: formulation development, pharmacokinetics and therapeutic potential. Indian J Chest Dis Allied Sci 2006; 48(3): 171-176.

14. Saraogi GK, Sharma B, Joshi B, Gupta P, Gupta UD, Jain NK, Agrawal GP. Mannosylated gelatin nanoparticles bearing isoniazid for effective management of tuberculosis. J Drug Target 2011; 19(3): 219-227.

15. Pandey R, Sharma A, Zahoor A, Sharma S, Khuller GK, Prasad B. Poly (DL-lactide-co-glycolide) nanoparticlebased inhalable sustained drug delivery system for experimental tuberculosis. J Antimicrob Chemother 2003; 52(6): 981-986.

16. Pandey R, Khuller GK. Subcutaneous nanoparticle-based antitubercular chemotherapy in an experimental model. J Antimicrob Chemother 2004; 54(1): 266-268.

17. Mullaicharam AR, Murthy RSR. Lung accumulation of niosome-entrapped rifampicin following intravenous and intratracheal administration in the rat. J Drug Deliv Sci Technol 2004; 14(2): 99-104.

18. Dhillon J, Fielding R, Adler-Moore J, Goodael RL, Mitchison $D$. The activity of low-clearance liposomal amikacin in experimental murine tuberculosis. $J$ Antimicrob Chemother 2001; 48(6): 869-876.

19. Zhang L, Pornpattananangku D, Hu CM, Huang CM. Development of nanoparticles for antimicrobial drug delivery. Curr Med Chem 2010; 17(6): 585-594.

20. Deol P, Khuller GK, Joshi K. Therapeutic efficacies of isoniazid and rifampin encapsulated in lung-specific stealth liposomes against Mycobacterium tuberculosis infection induced in mice. Antimicrob Agents Chemother 1997; 41(6): 1211-1214.

21. Labana S, Pandey $R$, Sharma S, Khuller GK. Chemotherapeutic activity against murine tuberculosis of once weekly administered drugs (isoniazid and

Trop J Pharm Res, January 2016; 15(1): 209 
rifampicin) encapsulated in liposomes. Int $J$ Antimicrob Agents 2002; 20(4): 301-304.

22. Okada M. Novel vaccines against $M$. tuberculosis. Kekkaku 2006; 81(12): 745-751.

23. Constantinides PP, Chaubal MV, Shorr R. Advances in lipid nanodispersions for parenteral drug delivery and targeting. Adv Drug Deliv Rev 2008; 60(6): 757-767.

24. Shafiq S, Shakeel F, Talegaonkar S, Ahmad FJ, Khar RK, Ali M. Development and bioavailability assessment of ramipril nanoemulsion formulation. Eur $J$ Pharm Biopharm 2007; 66(2): 227-243.

25. Ahmed M, Ramadan W, Rambhu D, Shakeel F. Potential of nanoemulsions for intravenous delivery of rifampicin. Pharmazie 2008; 63(11): 806-811.

26. Rainer HM, Dörte R, Stephan AR. Biodegradation of solid lipid nanoparticles as a function of lipase incubation time. Int J Pharm 1996; 144(1): 115-121.

27. Khan Ali A, Mudassir J, Mohtar N, Darwis Y. Advanced drug delivery to the lymphatic system: lipid-based nanoformulations. Int J Nanomedicine 2013; 8: 27332744.

28. Durgaramani $S$, Bindu $M$, Shalini DP, Sree TB. Formulation and Characterization of Solid Lipid Nanoparticles of Rifampicin. Erciyes Medical Journal 2013; 35(1): 1-5.

29. Singh $H$, Bhandari $R$, Kaur IP. Encapsulation of Rifampicin in a solid lipid nanoparticulate system to limit its degradation and interaction with Isoniazid at acidic pH. Int J Pharm 2013; 446(1-2): 106-111.

30. Espuelas MS, Legrand P, Loiseau PM, Bories C, Barratt $G$, Irache JM. In vitro antileishmanial activity of amphotericin B loaded in poly(epsilon-caprolactone) nanospheres. J Drug Target 2002; 10(8): 593-599.

31. Anisimova YV, Gelperina SI, Peloquin CA, Heifets LB. Nanoparticles as Antituberculosis Drugs Carriers: Effect on Activity Against Mycobacterium tuberculosis in Human Monocyte-Derived Macrophages. J Nanopart Res 2000; 2(2): 165-171.

32. Kisich KO, Gelperina S, Higgins MP, Wilson S, Shipulo E, Oganesyan E, Heifets L. Encapsulation of moxifloxacin within poly(butyl cyanoacrylate) nanoparticles enhances efficacy against intracellular Mycobacterium tuberculosis. Int J Pharm 2007; 345(1-2): 154-162.

33. Clemens $D L$, Lee $B Y$, Xue $M$, Thomas CR, Meng $H$, Ferris $D$, Nel AE, Zink Jl, Horwitz MA. Targeted intracellular delivery of antituberculosis drugs to Mycobacterium tuberculosis-infected macrophages via functionalized mesoporous silica nanoparticles. Antimicrob Agents Chemother 2012; 56(5): 2535-2545.

34. De Faria TJ, Roman M, de Souza NM, De Vecchi R, de Assis JV, dos Santos AL, Bechtold IH, Winter N, Soares $M J$, Silva $L P$, et al. An isoniazid analogue promotes Mycobacterium tuberculosis-nanoparticle interactions and enhances bacterial killing by macrophages. Antimicrob Agents Chemother 2012; 56(5): 2259-2267.

35. Kazi KM, Mandal AS, Biswas N, Guha A, Chatterjee S, Behera M, Kuotsu K. Niosome: A future of targeted drug delivery systems. J Adv Pharm Technol Res 2010; 1(4): 374-380.

36. Roopa K, Mamatha GC, Subramanya G, Udupa N. Preparation, characterization and tissue disposition of niosomes containing isoniazid. Rasayan J Chem 2008; 1(2): 224-227.

37. Gyanendra S, Harinath D, Shailendra KS, Shubhini AS. Niosomal Delivery of Isoniazid - Development and Characterization. Trop J Pharm Res 2011; 10 (2): 203210.

38. Jain CP, Vyas SP. Preparation and characterization of niosomes containing rifampicin for lung targeting. $J$ Microencapsul 1995; 12(4): 401-407.

39. Pavala RN, Suriyaprakash TNK, Senthamarai $R$. Formulation and Evaluation of Rifampicin and Gatifloxacin Niosomes on Logarithmic-Phase Cultures of Mycobacterium Tuberculosis. Int J Pharm Bio Sci 2010; 1(4): 379-387.

40. El-Ridy MS, Abdelbary A, Nasr EA, Khalil RM, Mostafa DM, El-Batal Al, Abd El-Alim SH. Niosomal encapsulation of the antitubercular drug, pyrazinamide. Drug Dev Ind Pharm 2011; 37(9): 1110-1118.

41. Koul A, Arnoult E, Lounis N, Guillemont J, Andries K. The challenge of new drug discovery for tuberculosis. Nature 2011; 469(7331): 483-490.

42. O'Brien RJ, Nunn PP. The need for new drugs against tuberculosis. Obstacles, opportunities, and next steps. Am J Respir Crit Care Med 2001; 163(5): 1055-1058.

43. Matteelli A, Carvalho AC, Dooley KE, Kritski A. TMC207: the first compound of a new class of potent antituberculosis drugs. Future Microbiol 2010; 5(6): 849858.

44. Lenaerts AJ, Hoff D, Aly S, Ehlers S, Andries K, Cantarero L, Orme IM, Basaraba RJ. Location of persisting mycobacteria in a Guinea pig model of tuberculosis revealed by r207910. Antimicrob Agents Chemother 2007; 51(9): 3338-3345.

45. Koul A, Vranckx L, Dendouga N, Balemans W, Van den Wyngaert I, Vergauwen K, Gohlmann HW, Willebrords $R$, Poncelet $A$, Guillemont $J$, et al. Diarylquinolines are bactericidal for dormant mycobacteria as a result of disturbed ATP homeostasis. J biol chem 2008; 283(37): 25273-25280.

46. Ibrahim M, Andries $K$, Lounis N, Chauffour A, TruffotPernot $C$, Jarlier $V$, Veziris $N$. Synergistic activity of R207910 combined with pyrazinamide against murine tuberculosis. Antimicrob Agents Chemother 2007; 51(3): 1011-1015.

47. Singh R, Manjunatha $U$, Boshoff HIM, Ha YH, Niyomrattanakit $P$, Ledwidge $R$, Dowd CS, Lee IY, Kim $P$, Zhang $L$, et al. PA-824 Kills Nonreplicating Mycobacterium tuberculosis by Intracellular NO Release. Science 2008; 322(5906): 1392-1395.

48. Tyagi S, Nuermberger E, Yoshimatsu $T$, Williams $K$, Rosenthal I, Lounis N, Bishai W, Grosset J. Bactericidal activity of the nitroimidazopyran PA-824 in a murine model of tuberculosis. Antimicrob Agents Chemother 2005; 49(6): 2289-2293.

Trop J Pharm Res, January 2016; 15(1): 210 
49. Andreas HD, Rodney D, Florian VG, Gregory S, Amour $V$, Peter RD, Christo VN, Daniel E, Helen W, Piet B, et al. 14-day bactericidal activity of PA-824, bedaquiline, pyrazinamide, and moxifloxacin combinations: a randomised trial. Lancet 2012; 380(9846): 986-993.

50. Matsumoto M, Hashizume H, Tomishige T, Kawasaki M, Tsubouchi $H$, Sasaki H, Shimokawa Y, Komatsu M. OPC-67683, a Nitro-Dihydro-Imidazooxazole Derivative with Promising Action against Tuberculosis In Vitro and In Mice. PLoS Med 2006; 3(11): e466.

51. Saliu OY, Crismale C, Schwander SK, Wallis RS. Bactericidal activity of OPC-67683 against drug-tolerant Mycobacterium tuberculosis. J Antimicrob Chemother 2007; 60(5): 994-998.

52. Jossy van den B., Gibson SK, Elton RK, Martin JB, Rob EA. Agents in Clinical Development Problems, Progress, and Evaluation of New Drugs against Tuberculosis. Antimicrob Agents Chemother 2009; 53 (3): 849-862.

53. Diekema DJ, Jones $R N$. Oxazolidinone antibiotics. Lancet 2001; 358(9297): 1975-1982.

54. Lee M, Lee J, Carroll MW, Choi H, Min S, Song T, Via LE, Goldfeder LC, Kang E, Jin B, et al. Linezolid for treatment of chronic extensively drug-resistant tuberculosis. N Engl J Med 2012; 367(16): 1508-1518.

55. Cox H, Ford N. Linezolid for the treatment of complicated drug-resistant tuberculosis: a systematic review and meta-analysis. Int J Tuberc Lung Dis 2012; 16(4): 447454.

56. Gwendolyn AM, Amit Nayyar, Eugene Uh, Sharon Y. Wong, Tathagata Mukherjee, Laura E. Via, Matthew Carroll, Rachel L. Edwards, Todd D. Gruber, Inhee Choi, et al. The Medicinal Chemistry of Tuberculosis Chemotherapy. In: Elliott $R$ editor. Third World Diseases: Springer Berlin Heidelberg; 2011. p 47-124.

57. Shaw KJ, Barbachyn MR. The oxazolidinones: past, present, and future. Ann N Y Acad Sci 2011; 1241: 4870.
58. Reele S, Xiao AJ, Das S, Balasubramanian V, Melnick D. A 14-day multiple ascending dose study: AZD5847 is well tolerated at predicted exposure for treatment of tuberculosis (TB). Poster session presented at: 51st Annual Inter-science Conference on Antimicrobial Agents and Chemotherapy; 2011 September 17-20; Chicago 2011: (Abstract A1-1735).

59. Protopopova M, Hanrahan $C$, Nikonenko B, Samala $R$, Chen P, Gearhart J, Einck. L., Nacy CA. Identification of a new antitubercular drug candidate, SQ109, from a combinatorial library of 1,2-ethylenediamines. $J$ Antimicrob Chemother 2005; 56(5): 968-974.

60. Grosset JH, Singer TG, Bishai WR. New drugs for the treatment of tuberculosis: hope and reality. Int $J$ Tuberc Lung Dis 2012; 16(8): 1005-1014.

61. Reddy VM, Dubuisson T, Einck L, Wallis RS, Jakubiec W, Ladukto L, Campbell S, Nacy CA. SQ109 and PNU100480 interact to kill Mycobacterium tuberculosis in vitro. J Antimicrob Chemother 2012; 67(5): 1163-1166.

62. Nikonenko BV, Protopopova M, Samala R, Einck L, Nacy $C A$. Drug Therapy of Experimental Tuberculosis (TB): Improved Outcome by Combining SQ109, a New Diamine Antibiotic, with Existing TB Drugs. Antimicrob Agents Chemother 2007; 51(4): 1563-1565.

63. Andreas HD, Alexander $P$, Martin $G$, Ramonde $P$, Roxana R, LiesI PS, Christoffel P, Rene K, Mampedi, B., , Gavin C, Amour V, et al. The Diarylquinoline TMC207 for Multidrug-Resistant Tuberculosis. N Engl J Med 2009; 360(23): 2397-2405.

64. Lienhardt C, Vernon A, Raviglione MC. New drugs and new regimens for the treatment of tuberculosis: review of the drug development pipeline and implications for national programmes. Curr Opin Pulm Med 2010; 16(3): 186-193.

65. Boris VN, Marina $P$, Rowena S, Leo E, Carol AN. Existing TB Drugs SQ109, a New Diamine Antibiotic, with (TB): Improved Outcome by Combining Drug Therapy of Experimental Tuberculosis. Antimicrob Agents Chemother 2007; 51(4): 1563-1565. 